\title{
KINERJA MICROBIAL FUEL CELLS PADA PENGOLAHAN LIMBAH CAIR PEMINDANGAN DENGAN MEMBRAN SEPARATOR CAMPURAN POLIMER KITOSAN/PVA
}

\section{PERFORMANCE OF MICROBIAL FUEL CELLS IN SALTED BOILED FISH PROCESSING WASTE WATER USING CHITOSAN/PVA POLYMER MEMBRANE SEPARATOR}

\author{
Bustami Ibrahim, Pipih Suptijah, dan Fajar Syahreza \\ Departemen Teknologi Hasil Perairan, Fakultas Perikanan dan Ilmu Kelautan, Institut Pertanian Bogor \\ Kampus IPB Darmaga, Jalan Agatis, Bogor 16680 Jawa Barat, Indonesia \\ Email: bustamibr@yahoo.com
}

Makalah: Diterima 2 Desember 2016; Diperbaiki 20 Juli 2017; Disetujui 2 Agustus 2017

\begin{abstract}
Separator attched to MFC system can reduce the distance between cathode and anode and limit oxygen penetration to anode chamber. The use of Chitosan/polyvinyl alcohol (PVA) mixture polymer as membrane separator was expected to have ability to increase electron recovery from the substrate. The objectives of this research were to increase the standard quality of wastewater of salted boiled fish processing and to increase bioelectricity generation, through the membrane separator adding to MFC system. Separator polymer was made by blending $2 \%$ chitosan and $5 \%$ PVA solution, in different ratio of chitosan $(K)$ and PVA $(P)$ at 2:3 $\left(K_{2} P_{3}\right), 1: 1$ $\left(K_{1} P_{1}\right), 3: 2\left(K_{3} P_{2}\right)$, and without separator. The study was carried out to measure electricity generated and to analyse of BOD, COD and TAN of the wastewater. The $\mathrm{K}_{2} \mathrm{P}_{3}$ treatment showed the highest electricity generation with average voltage of $0.50 \pm 0.06 \mathrm{~V}$, maximum current density $0,29 \mathrm{~mA} / \mathrm{cm}^{2}$, and maximum power density $15.40 \mathrm{~mW} / \mathrm{cm}^{2}$. The reduction of COD showed insignificantly different among treatments, but the reduction of $B O D$ and TAN values showed significantly different. The BOD value reduced to56.54\% in $K_{2} P_{3}$ treatment and the TAN value reduced to $92.73 \%$ in $K_{1} P_{1}$ treatment.
\end{abstract}

Keywords : chitosan, microbial fuel cell, polyvinil alcohol, separator

\section{ABSTRAK}

Separator pada sistem MFC dapat mengurangi jarak antara katode dan anode serta menghambat oksigen untuk masuk ke dalam ruang anode. Penggunaan polimer campuran kitosan/polyvinil alcohol (PVA) diharapkan dapat meningkatkan perolehan kembali electron dari substrat. Tujuan dari penelitian ini adalah meningkatkan baku mutu limbah cair pengolahan ikan pindang dan produksi listrik, dengan penambahan membran separator yang dibuat dari polimer campuran kitosan dan PVA. Polimer separator dibuat dengan mencampurkan $2 \%(\mathrm{~b} / \mathrm{v})$ kitosan dengan 5\% (b/v) PVA dalam perbandingan kitosan $(\mathrm{K})$ dan PVA $(\mathrm{P})$ yang berbeda yaitu, 2:3 $\left(\mathrm{K}_{2} \mathrm{P}_{3}\right)$, 1:1 $\left(\mathrm{K}_{1} \mathrm{P}_{1}\right)$, 3:2 $\left(\mathrm{K}_{3} \mathrm{P}_{2}\right)$, dan tanpa separator. Pengujian dilakukan meliputi pengukuran elektrisitas dananalisis parameter BOD, COD, dan TAN dari limbah. Nilai elektrisitas tertinggi diperoleh pada perlakuan $\mathrm{K}_{2} \mathrm{P}_{3}$ dengan rata-rata tegangan $0,50 \pm 0,06 \mathrm{~V}$, nilai rapat arus maksimum $0,29 \mathrm{~mA} / \mathrm{cm}^{2}$, dan nilai rapat daya maksimum 15,40 $\mathrm{mW} / \mathrm{cm}^{2}$. Penurunan nilai COD tidak memberikan hasil yang berbeda nyata. Penurunan nilai BOD dan TAN menunjukkan hasil yang berbeda nyata dengan persentase penurunan 56,54\% pada perlakukan $\mathrm{K}_{2} \mathrm{P}_{3}$ dan $92,73 \%$ pada perlakuan $\mathrm{K}_{1} \mathrm{P}_{1}$.

Kata kunci : air pemindangan, kitosan, microbial fuel cell, polyvinil alcohol, separator

\section{PENDAHULUAN}

Microbial Fuel Cell (MFC) adalah teknologi yang memanfaatkan bakteri untuk menghasilkan listrik dari material organik. Kelebihan dari MFC dalam pengolahan limbah yang lain adalah tidak diperlukan proses aerasi dan penggunaan energi listrik (Logan, 2008). Penelitian Ibrahim et al. (2014a), dan Ibrahim et al. (2014b) menunjukkan bahwa penggunaan limbah cair perikanan sebagai substrat dapat menghasilkan energi listrik dan berkurangnya beban organik dari limbah.

Tantangan terbesar dalam penerapan teknologi MFC adalah mengurangi biaya pembuatan elektroda dan menambah perolehan kembali elektron dari substrat. Penigkatan perolehan kembali elektron dan kinerja MFC akan berdampak pada peningkatan energi listrik yang dihasilkan oleh reaktor. Penggunaan separator antara katoda dan anoda menjadi bagian yang penting dalam desain reaktor MFC sebab dapat meningkatkan kinerja dari MFC.

Separator yang ideal menurut Hou et al. (2013) dapat menghambat transfer oksigen terhadap substrat, namun dapat membiarkan proton untuk masuk secara efisien dan dengan biaya yang murah. Polyvinyl Alkohol (PVA) sebagai membran separator MFC dapat menjadi alternatif. Kemampuan yang dimiliki PVA menurut An et al.(2011) adalah untuk mengurangi terjadinya fouling. Disamping itu 
penelitian Hoskins et al. (2014) menunjukkan bahwa penggunaan PVA sebagai separator dapat meningkatkan produksi daya yang dihasilkan sampai $444 \pm 8 \mathrm{~mW} / \mathrm{m}^{2}$. Kitosan merupakan polimer yang banyak digunakan dalam berbagai bidang salah satunya dalam aplikasi fuel cell terutama kaitannya dengan elektrode seperti pada penelitian $\mathrm{Ma}$ et al.(2011) yang digunakan sebagai binder dan separator untuk elektrode dalam borohydride fuel cell.

Crosslinking merupakan salah satu cara yang umum digunakan dalam memodifikasi kitosan. Modifikasi polimer kitosan dan PVA secara crosslinking dan digunakan sebagai separator dapat menjadi solusi terhadap efisiensi pemanfaatan energi pada MFC. Yang dan Hsien (2012) menyatakan modifikasi secara crosslinking membuat polimer campuran akan memiliki kelebihan dari PVA dan juga kitosan.

Penelitian ini berkaitan dengan energi listrik statis yang dihasilkan dan pengolahan limbah pada MFC single-chamber air cathode dengan menggunakan separator elektrode dari polimer campuran kitosan/PVA. Penelitian ini bertujuan untuk meningkatkan baku mutu limbah cair pengolahan ikan pindang dan produksi listriknya, dengan penambahan membran separator yang terbuat dari polimer campuran kitosan dan PVA pada sistem MFC.

\section{BAHAN DAN METODE}

\section{Bahan dan Alat}

Limbah cair yang digunakan pada penelitian ini berasal dari limbah cair pemindangan ikan PT. Cindy Grup Parung, Bogor. Bahan-bahan kimia yang digunakan yaitu asam asetat, karbon aktif, stainless mesh 50x50, kabel tembaga, kitosan dengan Derajat Deasetilasi (DD) $>80 \%$, PVA, asam sulfat, $\mathrm{K}_{2} \mathrm{Cr}_{2} \mathrm{O}_{7} 0,25 \mathrm{~N}$, Ferrous ammonium sulfate $\left[\mathrm{Fe}\left(\mathrm{NH}_{4}\right)_{2}\left(\mathrm{SO}_{4}\right)_{2}\right] \quad 0,2 \mathrm{~N}, \mathrm{NaOH}$, Asam Borat $\left(\mathrm{H}_{3} \mathrm{BO}_{3}\right)$, Indikator bromchresol green, dan Indikator methyl red. Peralatan analisis yang digunakan adalah multimeter (Sanwa, YX360TRF) untuk mengukur elektrisitas MFC.

\section{Metode}

\section{Desain MFC single-chamber}

Desain MFC berbentuk kubus singlechamber dengan air-chatode berdimensi $8 \times 8 \times 8$ $\mathrm{cm}^{3}$ dengan volume $512 \mathrm{~mL}$. Anode yang digunakan adalah pelat karbon aktif dengan binder kitosan $4 \%$ dengan kabel tembaga ditautkan yang berfungsi sebagai penerima arus. Pembuatan katode dilakukan menurut Yang et al. (2014) dengan kitosan sebagai bahan pengikat untuk katode. Skema sistem MFC yang digunakan dalam penelitian ini disajikan seperti pada Gambar 1.

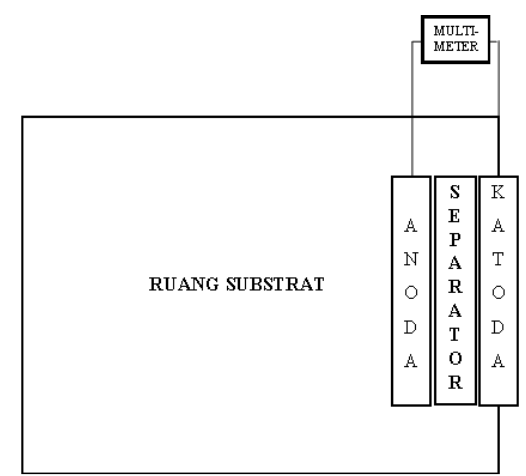

Gambar 1. Skema sistem MFC single chamber dengan separator

\section{Pembuatan Bahan Pengikat}

Pembuatan larutan untuk bahan pengikat dilakukan dengan larutan kitosan 4\%. Larutan diaduk hingga homogen. Larutan yang telah homogen didiamkan dengan kondisi suhu ruang selama 12 jam untuk degassing.

\section{Pembuatan Katode dan Anode}

Kerangka dalam pembuatan katode menggunakan stainless mesh 50 x 50 dipotong berbentuk persegi panjang dengan luas $16 \mathrm{~cm}^{2}(4 \mathrm{~cm}$ x $4 \mathrm{~cm}$ ). Stainless mesh kemudian dioleskan dengan campuran karbonaktif dengan larutan binder secara merata pada salah satu sisinya, setelah rata kemudian direndam kedalam aquades, bagian yang diolesi karbonaktif direndam menghadap ke bawah. Katode yang telah direndam, dikeringkan didalam ruang asam selama 8 jam. Penelitian ini menggunakan model SEA (Separator Electrode Assembly) katode dilapisi dengan separator polimer PVA-kitosan. Penempatan anode menempel pada bagian separator katode.

\section{Pembuatan Polimer Separator}

Polimer separator dibuat menggunakan metode Yang et al. (2004) dan Pieróg et al. (2009). Larutan kitosan yang digunakan berkonsentrasi $2 \%$ dengan melarutkan kitosan dengan pelarut asam asetat, dibiarkan selama satu hari untuk menghilangkan gelembung yang terdapat dalam larutan. Larutan PVA 5\% dibuat dengan pelarut aquades pada suhu $80^{\circ} \mathrm{C}$ selama 1 jam. Perbandingan campuran antara larutan kitosan dengan larutan PVA sebagai berikut, $2: 3,1: 1$, dan 3:2, kemudian diaduk menggunakan magnetic stirrer selama 12 jam. Campuran larutan yang telah diaduk didiamkan sampai seluruh buih hilang. Campuran polimer dituang kedalam cetakan dan dikeringkan pada suhu ruang selama 48 jam. Campuran polimer yang sudah mengering dilepaskan dari cetakan, kemudian dipotong seukuran dengan elektrode. Film polimer campuran kemudian direndam kedalam $\mathrm{NaOH} 2 \mathrm{M}$ selama 10 menit. Film dibilas dengan aquades kemudian dikeringkan. Film yang telah mengering direndam kedalam larutan asam sulfat $0,5 \mathrm{M}$ selama 
1 jam, kemudian dibilas dengan aquades dan disimpan dalam kondisi terendam dalam aquades.

\section{Analisis Elektrisitas}

Analisis pendahuluan dilakukan dengan mengukur nilai hambatan dan konduktivitas pada katoda sebelum dan sesudah pelapisan separator pada tiap perlakuan. Tegangan yang melewati resistor direkam setiap 1 jam. Elektrisitas direkam seperti pada penelitian Watson et al. (2011) pada tiap hambatan yang diberikan. Rumus perhitungan elektrisitas mengikuti Logan et al. (2006), kerapatan arus (densitas arus) dihitung berdasarkan $\mathrm{I}=\mathrm{E} / \mathrm{R}$, dan dibagi luas permukaan anode $\left(\mathrm{cm}^{2}\right)$, dimana I adalah arus (A), E adalah tegangan yang terukur (V), dan $\mathrm{R}$ adalah hambatan luar $(\Omega)$, rapat daya $\mathrm{P}(\mathrm{W})$ dihitung berdasarkan $\mathrm{P}=\mathrm{I} \mathrm{E}$, dan dibagi luas permukaan anoda.

\section{Analisis Limbah}

Pengujian limbah dilakukan dengan mengukur limbah sebelum dan sesudah proses operasi MFC. Analisis yang dilakukan diantaranya, pengukuran Chemical Oxygen Demand (COD), Biological Oxygen Demand (BOD), dan Total Amoniak Nitrogen (TAN) dihitung berdasarkan metodeAPHA (1999).

\section{HASIL DAN PEMBAHASAN}

\section{Elektrisitas MFC}

Pengukuran tegangan yang dilakukan selama 36 jam menunjukan perlakuan $\mathrm{K}_{2} \mathrm{P}_{3}$ memiliki nilai rata-rata tegangan tertinggi diantara semua perlakuan sebesar $0,50 \pm 0,06$ V. Perlakuan lain mengalami penurunan dilihat dari rata-rata nilai tegangan yang dihasilkan mulai dari $\mathrm{K}_{1} \mathrm{P}_{1}, \mathrm{~K}_{3} \mathrm{P}_{2}$, dan $\mathrm{NS}$, secara berurut memiliki nilai tegangan $0,46 \pm$ $0,04 \mathrm{~V}, 0,37 \pm 0,05 \mathrm{~V}$, dan 0,31 $\pm 0,05 \mathrm{~V}$. Hasil ini lebih besar dibandingkan reaktor MFC model
Spaced Electrode (SPA) Ibrahim et al. (2014a) dengan nilai rata-rata tegangan tertinggi pada perlakuan dua elektrode sebesar 0,213 V. Hasil pengamatan tegangan selama 36 jam dapat dilihat pada Gambar 2.

Perlakuan menunjukkan nilai fluktuatif pada setiap jam, namun dilihat dari jam ke-1 pada perlakuan $\mathrm{K}_{2} \mathrm{P}_{3}$ menunjukan nilai tegangan sebesar $0,54 \mathrm{~V}$ diikuti perlakuan lainnya berurut $0,38 \mathrm{~V}$, $0,33 \mathrm{~V}$, dan 0,26 V. Kenaikan terjadi pada jam-jam awal, kemudian mengalami sedikit penurunan, pada tiap perlakuan dengan jam yang berbeda. Riyanto et al. (2012) mengatakan nilai tegangan yang terjadi pada jam awal disebabkan oleh elektron yang sudah terdapat pada substrat sebelumnya kenaikan yang terjadi berikutnya disebabkan oleh aktivitas bakteri yang mulai memecah substrat.

Perlakuan $\mathrm{K}_{2} \mathrm{P}_{3}$ memiliki nilai tegangan tertinggi, diikuti oleh $\mathrm{K}_{1} \mathrm{P}_{1}, \mathrm{~K}_{3} \mathrm{P}_{2}$, dan NS memiliki nilai terendah. Rata-rata tegangan yang dihasilkan pada setiap perlakuan $\mathrm{K}_{2} \mathrm{P}_{3}, \mathrm{~K}_{1} \mathrm{P}_{1}, \mathrm{~K}_{3} \mathrm{P}_{2}$, dan NS secara berurut adalah $0,50 \mathrm{~V}, 0,46 \mathrm{~V}, 0,37 \mathrm{~V}$, dan 0 , $31 \mathrm{~V}$. Hal ini menunjukkan penggunaan separator dapat meningkatkan tegangan yang dihasilkan pada MFC. Perbedaan tegangan yang dihasilkan pada tiap perlakuan menunjukkan perbandingan kitosan dan PVA mempengaruhi tegangan yang dihasilkan.

Kitosan memiliki dua grup fungsional dalam senyawanya yaitu grup amina dan hidroksil. Dalam air grup amina akan terprotonisasi oleh proton yang berasal dari anode. Kemudian proton diteruskan ke katode yang menyebabkan peningkatan konduktivitas ion. Menurut Hoskin (2014), air tawar memiliki konduktivitas ion yang rendah sehingga separator kitosan/PVA sangat membantu meningkatkan konduktivitas, terbukti pada penelitian yang tidak menggunakan separator (NS) menghasilkan tegangan listrik yang paling rendah.

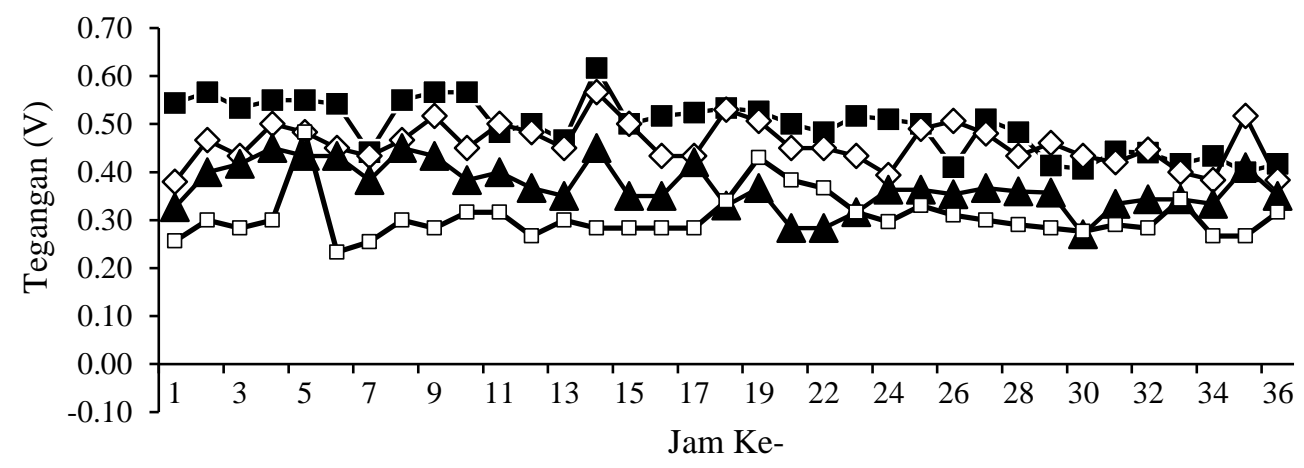

Gambar 2. Nilai Tegangan pada tiap jam pengamatan $(\square) \mathrm{K}_{2} \mathrm{P}_{3},(\diamond) \mathrm{K}_{1} \mathrm{P}_{1},(\boldsymbol{\Lambda}) \mathrm{K}_{3} \mathrm{P}_{2}$, $(\square)$ non separator 
Perbedaan perbandingan kitosan/PVA menunjukkan adanya perbedaan antara tegangan dan arus yang dihasilkan selama pengamatan. Perlakuan $\mathrm{K}_{2} \mathrm{P}_{3}$ memiliki nilai tegangan dan kerapatan arus maksimum sebesar $0,29 \mathrm{~mA} / \mathrm{cm}^{2}$ dan menghasilkan tegangan sebesar $0,55 \mathrm{~V}$. Perlakuan $\mathrm{K}_{1} \mathrm{P}_{1}$ memiliki rapat arus maksimum sebesar $0,26 \mathrm{~mA} / \mathrm{cm}^{2}$ dan menghasilkan tegangan sebesar $0,47 \mathrm{~V}$, rapat arus pada perlakuan ini lebih kecil dibandingkan dengan pada perlakuan $\mathrm{K}_{2} \mathrm{P}_{3}$. Nilai rapat arus dari perlakuan $\mathrm{K}_{3} \mathrm{P}_{2}$ sebesar $0,03 \mathrm{~mA} / \mathrm{cm}^{2}$ dan menghasilkan tegangan $0,46 \mathrm{~V}$. Perlakuan NS menunjukkan rapat arus sebesar $0,02 \mathrm{~mA} / \mathrm{cm}^{2}$ dengan tegangan sebesar $0,32 \mathrm{~V}$. Grafik hubungan tegangan dan rapat arus dapat dilihat pada Gambar 3.

Perlakuan $\mathrm{K}_{2} \mathrm{P}_{3}$ memiliki tingkat nilai tegangan dan rapat arus tertinggi. Perlakuan $\mathrm{K}_{1} \mathrm{P}_{1}$ mengalami sedikit penurunan seiring pertambahan rapat arus yang dihasilkan. Kenaikan terjadi pada perlakuan $\mathrm{K}_{3} \mathrm{P}_{2}$ secara signifikan seiring bertambahnya rapat arus yang dihasilkan, sementara perlakuan non separator memiliki tegangan yang relatif konstan yaitu berada pada kisaran $0,3 \mathrm{~V}$ dengan seiring pertambahan rapat arus yang dihasilkan. Peningkatan hambatan pada MFC dapat disebabkan oleh pembentukan biofilm pada katode. Wei et al. (2013) menyatakan kinerja pada MFC dapat menurun akibat keberadaan biofilm yang menjadi biofouling pada katoda sehingga meningkatkan hambatan dalam pada MFC.

Arus yang dihasilkan dari MFC, pada tiap perlakuan menunjukkan secara keseluruhan mengalami peningkatan rapat daya. Peningkatan yang dihasilkan oleh tiap perlakuan berbeda-beda. Grafik hubungan rapat daya dengan rapat arus dapat dilihat pada Gambar 4.

Nilai rapat daya perlakuan $\mathrm{K}_{2} \mathrm{P}_{3}$ memiliki kenaikan tertinggi dengan nilai maksimal yaitu, $16,12 \mathrm{~mW} / \mathrm{cm}^{2}$ diikuti dengan perlakukan $\mathrm{K}_{1} \mathrm{P}_{1}$ sebesar $12,86 \mathrm{~mW} / \mathrm{cm}^{2}, \mathrm{~K}_{3} \mathrm{P}_{2}$ sebesar $10,77 \mathrm{~mW} / \mathrm{cm}^{2}$, dan perlakuan NS sebesar $8,33 \mathrm{~mW} / \mathrm{cm}^{2}$. Seiring rapat arus yang meningkat, rapat daya yang dihasilkan akan semakin meningkat. Perbedaan ini disebabkan beberapa hal yaitu, bahan katode dan anode, keberadaan separator, dan perbedaan substrat. Penggunaan separator kitosan/PVA lebih bersifat membran penukar kation dapat meningkatkan daya yang dihasilkan, akan tetapi menghambat penghantaran anion dari katode ke anode.

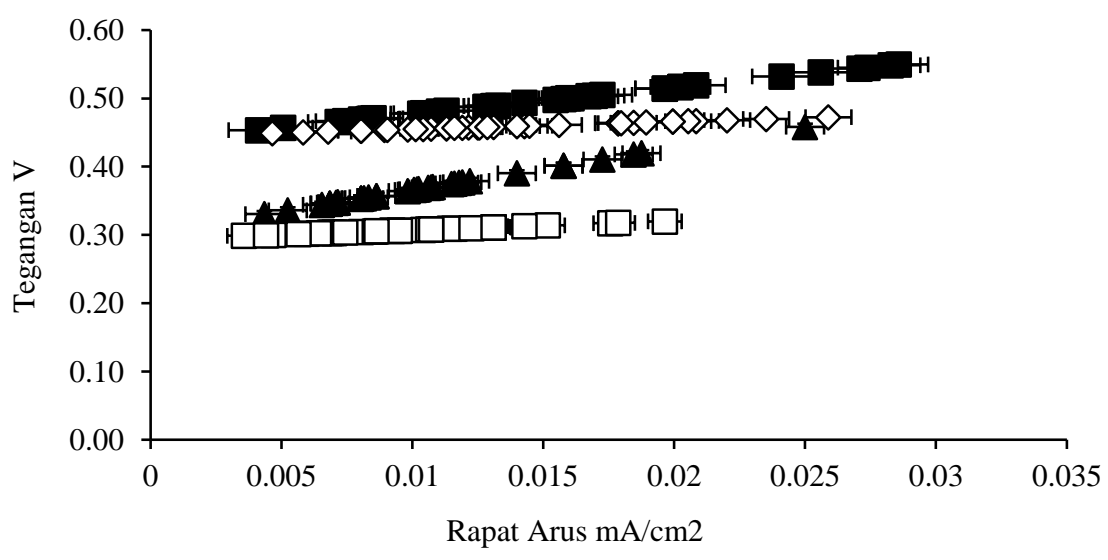

Gambar 3. Kurva hubungan tegangan dengan rapat arus $(\boldsymbol{\square}) \mathrm{K}_{2} \mathrm{P}_{3},(\diamond) \mathrm{K}_{1} \mathrm{P}_{1},(\boldsymbol{\Delta}) \mathrm{K}_{3} \mathrm{P}_{2}$, ( $\square$ ) NS

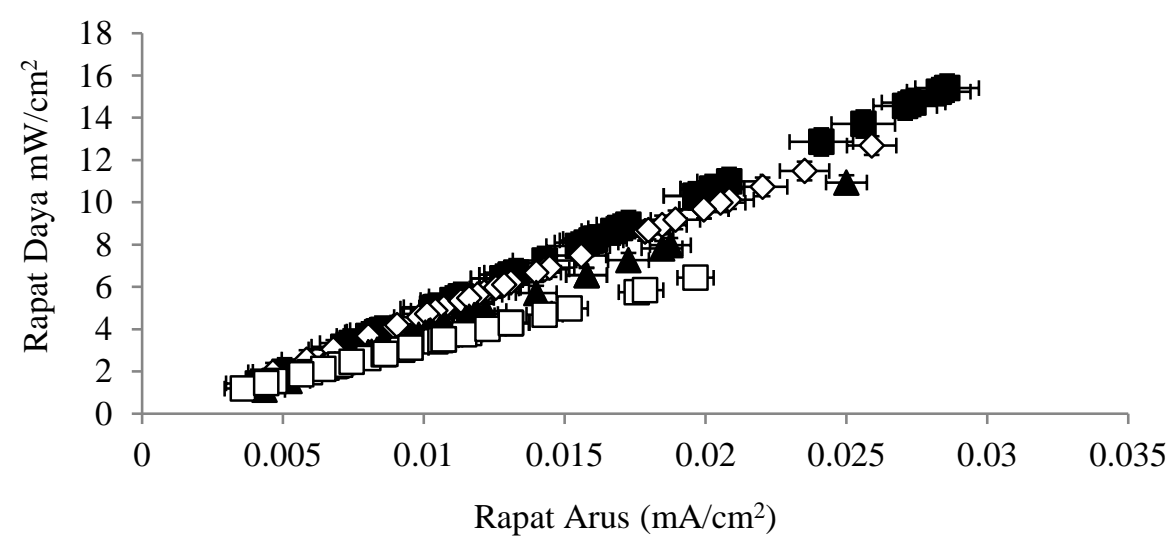

Gambar 4. Kurva hubungan rapat daya dengan rapat arus $(\square) \mathrm{K}_{2} \mathrm{P}_{3},(\diamond) \mathrm{K}_{1} \mathrm{P}_{1},(\boldsymbol{\Lambda}) \mathrm{K}_{3} \mathrm{P}_{2},(\square) \mathrm{NS}$ 
Hal ini menurut Ahn et al. (2014) dapat menurunkan masuknya oksigen dari luar ke dalam ruang anoda, yang akan berdampak pada menurunnya aktivitas mikroba aerobik dalam mendegradasi bahan organik dalam limbah. Chen et al. (2013), penggunaan separator terutama dengan PVA selain dapat menghambat masuknya oksigen dari luar, juga dapat menghambat penumpukan biofilm pada katode. Peningkatan hambatan karena biofilm pada MFC dapat menurunkan nilai daya yang dihasilkan.

\section{Karakteristik Limbah Cair Pengolahan Pindang}

Karakteristik limbah cair merupakan hal yang penting untuk diketahui pada tahap awal proses pengolahan limbah cair. Limbah cair pemindangan memiliki beban organik yang lebih tinggi dibandingkan dengan karakteristik limbah pengalengan, kecuali pada nilai TAN yang jauh lebih rendah dibandingkan dengan limbah pengalengan.

Hasil karakteristik limbah ini jauh lebih kecil dibandingkan dengan data pada penelitian Riaño et al. (2011) terutama pada ketiga parameter. Nilai COD dan BOD yang tinggi pada limbah cair pemindangan merupakan salah satu karakteristik dari limbah cair perikanan, Chowdhury et al. (2010) mengatakan sebagian besar beban organik dari limbah perikanan adalah berasal dari lemak dan protein, dan penambahan bahan-bahan lain selama proses pengolahan.

\section{Kondisi Limbah Setelah Proses Pengolahan dengan MFC}

Limbah cair pengolahan pemindangan yang dijadikan substrat untuk MFC, menunjukkan adanya penurunan pada beban organik yang terdapat didalam limbah. Penurunan yang terjadi berbeda pada tiap perlakuan. Hasil analisis COD dapat dilihat pada Gambar 5.

Nilai COD terendah terdapat pada perlakuan $\mathrm{K}_{3} \mathrm{P}_{2}$ sebesar $1024 \pm 57,69 \mathrm{~m} / \mathrm{L}$ atau laju penurunan sebesar $8,13 \%$. nilai COD terbesar terdapat pada perlakuan $\mathrm{K}_{1} \mathrm{P}_{1}$ dengan nilai $\mathrm{COD}$ menjadi $1008 \pm 57,69 \mathrm{mg} / \mathrm{L}$ atau dengan laju penurunan sebesar 9,56\%. Analisis ANOVA menunjukkan bahwa perbedaan nilai COD tidak memberikan perbedaan yang berbeda nyata terhadap perlakuan perbandingan komposisi membran separator. Penurunan COD antar perlakuan menunjukkan tidak adanya perbedaan yang signifikan. Menurut Ibrahim et al. (2014a) penurunan nilai COD yang tidak signifikan disebabkan waktu operasi MFC yang relatif singkat. Waktu operasi MFC selama 36 jam diduga belum cukup untuk mengolah limbah yang terdapat dalam substrat.

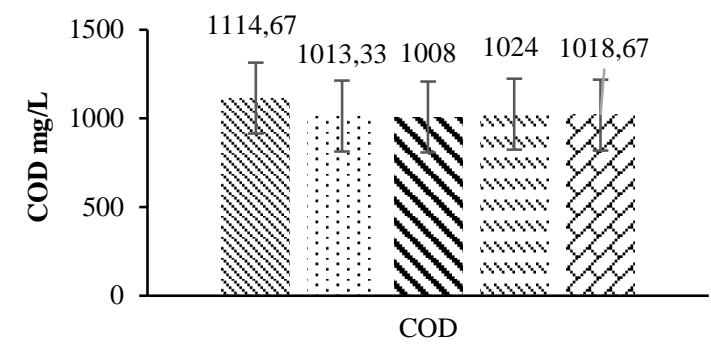

Gambar 5. Diagram Penurunan nilai COD (凹) sebelum, (回) $\mathrm{K}_{2} \mathrm{P}_{3},(\boldsymbol{\nabla}) \mathrm{K}_{1} \mathrm{P}_{1},(\boldsymbol{\Xi}) \mathrm{K}_{3} \mathrm{P}_{2}$, (D) NS

Nilai BOD menunjukkan penurunan secara signifikan dan menunjukkan adanya perbedaan yang nyata antar tiap perlakuan. Penurunan nilai BOD tertinggi terdapat pada perlakuan $\mathrm{K}_{2} \mathrm{P}_{3}$ sebesar $45,33 \pm 1,53 \mathrm{mg} / \mathrm{L}$ atau $56,54 \%$ dan terendah pada perlakuan $\mathrm{K}_{1} \mathrm{P}_{1}$ sebesar $91,33 \pm 3,06 \mathrm{mg} / \mathrm{L}$ atau $12,46 \%$. Diagram penurunan hasil BOD dapat dilihat pada Gambar 6.

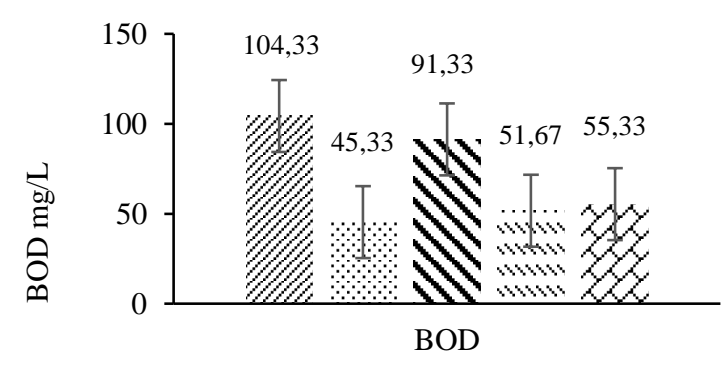

Gambar 6. Diagram Penurunan nilai BOD (因)

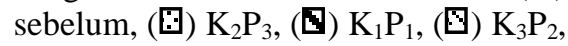
(D) NS

Tabel 1. Karakterisasi limbah cair pemindangan

\begin{tabular}{llcc}
\hline Parameter & Satuan & Limbah cair pemindangan & $\begin{array}{c}\text { Limbah } \\
\text { pengalengan* }\end{array}$ \\
\hline COD & $\mathrm{mg} / \mathrm{L}$ & $1114,67 \pm 186,82$ & 571 \\
$\mathrm{BOD}$ & $\mathrm{mg} / \mathrm{L}$ & $104,33 \pm 1,53$ & 184 \\
$\mathrm{TAN}$ & $\mathrm{mg} / \mathrm{L}$ & $0,83 \pm 0,016$ & 111 \\
\hline
\end{tabular}

*Ibrahim et al. (2007) 
Nilai BOD mengalami penurunan disebabkan oleh tingginya nilai elektrisitas yang dihasilkan oleh MFC terutama pada perlakuan $\mathrm{K}_{2} \mathrm{P}_{3}$. Penelitian Greenman et al. (2009) menunjukkan bahwa penggunaan teknologi MFC memiliki kemampuan yang sebanding dalam menurunkan nilai $\mathrm{BOD}_{5}$ dengan dibandingkan oleh teknologi filter aerasi pada kontrol kondisi yang sama, dan terdapat hubungan yang linear antara elektrisitas yang dihasilkan dengan konsentrasi nilai $\mathrm{BOD}_{5}$ yang terdapat pada substrat. Maharaj dan Parneet (2015) menyatakan korelasi linier antara nilai material organik, yaitu BOD dengan energi listrik yang dihasilkan disebabkan bakteri yang menempel pada permukaan anode, mendegradasi material organik dalam kondisi anaerobik. Hal ini menyebabkan terbentuknya reaksi degradasi, karbon dioksida, proton, dan elektron.

Hasil total amoniak nitrogen pada substrat setelah operasi MFC menunjukan penurunan pada setiap perlakuan. Analisis ANOVA menunjukkan bahwa terdapat penurunan yang berbeda nyata terhadap nilai TAN dengan perbedaan membran separator. Diagram penurunan nilai TAN dapat dilihat pada Gambar 7.

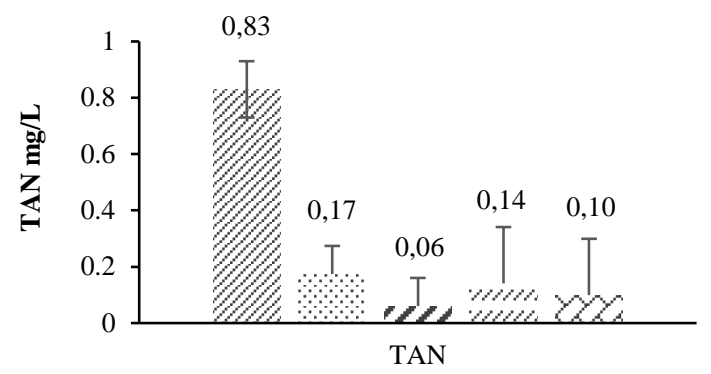

Gambar 7. Diagram Penurunan nilai TAN ( $\mathbf{Q})$ sebelum, (田) $\mathrm{K}_{2} \mathrm{P}_{3}$, (苂) $\mathrm{K}_{1} \mathrm{P}_{1}$, (寻) $\mathrm{K}_{3} \mathrm{P}_{2}$, (囚) NS

Gambar 7 menunjukkan penurunan tertinggi terdapat pada perlakuan $\mathrm{K}_{1} \mathrm{P}_{1}$ dengan nilai TAN setelah operasi sebesar $0,06 \pm 0,051 \mathrm{mg} / \mathrm{L}$ atau dengan penurunan sebesar $92,73 \%$ dan terendah pada perlakuan $\mathrm{K}_{2} \mathrm{P}_{3}$ sebesar $0,17 \pm 0,01 \mathrm{mg} / \mathrm{L}$ atau 79,03\%. Hasil ini lebih kecil dibandingkan dengan Yan et al. (2012) dengan pengkayaan biofilm nitrifikasi, yang menghasilkan nilai penurunan total nitrogen sebesar $96 \%$ namun memiliki hasil rapat daya yang lebih rendah sebesar $900 \pm 25 \mathrm{~mW} / \mathrm{m}^{2}$ dibandingkan dengan hasil pada penelitian ini. Wolf et al. (2007) mengatakan penurunan TAN pada proses pengolahan limbah cair perikanan disebabkan volatilisasi dan asimilasi ammonia.

\section{KESIMPULAN DAN SARAN}

\section{Kesimpulan}

Komposisi membran separator dari bahan campuran kitosan/PVA memberikan pengaruh terhadap elektrisitas MFC. Perlakuan $\mathrm{K}_{2} \mathrm{P}_{3}$ memiliki kenaikan nilai rapat arus, tegangan, dan rapat daya tertinggi. Perbedaan perlakuan memberikan pengaruh pada nilai BOD dan TAN, akan tetapi tidak mempengaruhi nilai COD. Perlakuan $\mathrm{K}_{2} \mathrm{P}_{3}$ menghasilkan nilai BOD sebesar 45,33 $\pm 1,53 \mathrm{mg} / \mathrm{L}$ dan perlakuan $\mathrm{K}_{1} \mathrm{P}_{1}$ menghasilkan nilai TAN sebesar $0,06 \pm 0,051 \mathrm{mg} / \mathrm{L}$.

\section{Saran}

Penelitian selanjutnya diperlukan adanya pengamatan dalam jangka waktu yang lama (longterm) dan secara kontinu untuk dapat melihat perbedaan laju penurunan beban organik. Penelitian selanjutnya diharapkan dapat mengamati MFC dengan proses jangka panjang dan menguji penurunan beban organik setiap interval waktu, untuk dapat menunjukan laju penurunan antar perlakuan dengan lebih jelas.

\section{DAFTAR PUSTAKA}

[APHA]American Public Health Association. 1999. Standar Methods for the Examination of Water and Wastewater $20^{\text {th }} \mathrm{ed}$. New York (US): American Public Health Association.

Ahn Y, Marta CH, Fang Z, Bruce EL. 2014. Different electrode configurations to optimize performance of multi-electrode microbial fuel cells for generating power or treating domestic wastewater. Journal of Power source. 249 : 440-445.

An Q, Feng L, Yanli J, Huanlin C. 2011. Influence of polyvinyl alcohol on the surface morphology, separation and anti-fouling performance of the composite polyamide nanofiltration membranes. Journal of Membranes Science. 367 : 158-165.

Chen G, Fang Z, Bruce EL, Michael AH. 2013. Poly (vinyl alcohol) separators improve the coulumbic efficiency of activated carbon chatodes in microbial fuel cells. Electrochemistry Communications. 34 : 150-152.

Chowdhury P, Viraraghavan T, dan Srinivasan A. 2010. Biological treatment process for fish processing wastewater-A review. Bioresource Technology. 101 : 439-449.

Greenman J, Antonio G, Lorenzo G, Ioannis I. 2009. Electricity from landfill leachate using microbial fuel cells : Comparison with biological aerated filter. Enzyme and Microbial Technology. 44 : 112-119.

Hoskins DL, Xiaoyuan Z, Michael AH, Bruce EL. 2014. Spray-on polyvinyl alcohol separators an impact on power production in air-cathode microbial fuel cells with different solution conductivities. Bioresource Technology. 172 : 156-161. 
Hou Y, Kaiming L, Haiping L, Guangli L, Renduo Z, Bangyu Q, Shanshan C. 2013. Using crosslinked polyvinyl alcohol polymer membrane as a separator in the microbial fuel cell. Frontiers Environmental Science Engineering. 8 (1) : 137-143.

Ibrahim B. 2007. Studi penyisihan nitrogen air limbah agroindustri hasil perikanan secara biologis dengan model dinamik activated sludge model ( ASM) 1 [Disertasi]. Bogor (ID) : Sekolah Pasca Sarjana Institut Pertanian Bogor.

Ibrahim B, Ella S, dan Rico A. 2014a. Pembangkit biolistrik dari limbah cair industri perikanan menggunakan microbial fuel cell dengan jumlah elektroda yang berbeda. Dinamika Maritim. IV (1) : 1-9.

Ibrahim B, Pipih S, dan Syeila R. 2014b. Kinerja rangkaian seri sistem microbial fuel cell sebagai penghasil biolistrik dari limbah cair perikanan. JPHPI. 17(1) : 71-79.

Logan BE. 2008. Microbial Fuel Cells. New Jersey (US): Wiley.

Logan BE, Bert H, Rene R, Uwe S, Jurg K, Stefano F, Peter A, Willy V, Kornel R. 2006. Microbial fuel cell : methodology and technology. Environment Science Technology. (40) $17:$ 5181-5192.

Ma J, Nurul AC, Yogeshwar S, Rudolph GB. 2011. A high performance direct borohydride fuel cell employing cross-linked chitosan membrane. Journal of Power Sources. 196 : 8257-8264.

Maharaj KT dan Parneet P. 2015. Performance of pilot-scale microbial fuel cells treating wastewater with associated bioenergy production in the Carribean context. International Journal Energy Environmental Engginering. 6 : 213-220.

Pieróg M, Gierszewska-Drużyńska M, OstrowskaCzubenko J. 2009. Effect ofionic crosslinking agents on swelling behaviour of chitosan hydrogelmembranes. Progress on Chemistry and Application of Chitin and Its. 14:75-82.
Riaño B, Molinuevo B, Garcia-gozales M.C. 2011. Treatment of fish processing wastewater with microalga-containing microbiota. Bioresource Technology. 102 : 1082910833.

Riyanto B, Akhiruddin M, dan Yayan F. 2012. Degradasi bahan organik dan pemanfaatan arus listrik pada sedimen tambak udang tradisional melalui microbial fuel cell. JPHPI. 15 (3) : 183-192.

Watson VJ, Tomonori S, Michael AH, Bruce EL. 2011. Polymer coating as separator layers for microbial fuel cell cathodes. Journal of Power Sources. 196 : 3009-3014.

Wei B, Justin CT, Fang Z, Younggy K, Bruce EL. 2013. Electrochemical analysis of separators used in single-chamber, air cathode microbial fuel cells. Electrochimia Acta. 89 : 45-51.

Wolf G, Cristian P, Van Loosdrect M. 2007. Kinetic modelling of phototrophic biofilms : the PHOBIA model. Biotechnology and Bioengineering. 97 (5) : 1064-1079.

Yan H, Tomonori S, dan John MR. 2012. Nitrogen removal in single-chamber microbial fuel cell with nitrifying biofilm enriched at the air cathode. Water Research. 46 : 22152224.

Yang JM, Su WY, Leu TL, Yang MC. 2004. Evaluation of chitosan/ PVA blendedhydrogel membranes. Journal of Membrane Science. 236:39-51.

Yang Ming J dan Hsien Chih C. 2012. Preparation and characterization of polyvinyl alcohol/chitosan blended membrane for alkaline direct methanol fuel cells. Jornal of Membrane Science. 419-420 : 65-71.

Yang W, Weihua H, Fang Z, Michael AH, Bruce EL. 2014. Single-step fabrication using a phase inversion method of poly (vinyl fluoride) (PVDF) activated carbon air cathodes for microbial fuel cells. Environment Science Technology Letter. I (10) : 416-420. 